\title{
O impeachment de Dilma e a crise do lulismo
}

Tiago Nogara

SINGER, A. O lulismo em crise: um quebra-cabeça do período Dilma (2011-2016). São Paulo: Companhia das Letras, 2018.

Escrita ainda no calor da tortuosa crise política e econômica que assola o Brasil, a obra de André Singer complementa seu já consagrado "Os sentidos do lulismo", provendo ferramentas de altíssima qualidade para os que buscam analisar e compreender as complexas movimentaçóes operadas no cenário político brasileiro dos derradeiros anos do projeto lulista. Recheada de inúmeras polêmicas, habilmente expostas pelo autor, a obra não apenas rediscute os vários eventos políticos que conformaram a crise gestada entre 2011-2016, como também propóe consistentes eixos teóricos para uma análise mais ampla dos acontecimentos que marcaram a história contemporânea brasileira, apresentando propostas como a dos três partidos reais da democracia representativa e do chamado movimento pendular da burguesia industrial.

Partindo da premissa de coexistência de um setor moderno e um atrasado na sociedade brasileira, Singer aponta que esta divisão resulta na conformação de um setor moderno grande o suficiente para impor vetos sobre a mudança das estruturas desta mesma sociedade. Assim, ao invés de indicar o atraso como responsável por impedir a ascensão do moderno, Singer indica no próprio vigor político do setor moderno a responsabilidade pela

Mestrando do Programa de Pós-Graduação em Relações Internacionais (PPGRI), da Universidade de Brasília (UnB).

\section{$(\infty))$ EY}

Direito autoral e licença de uso: Este artigo está licenciado sob uma Licença Creative Commons. Com essa licença você pode compartilhar, adaptar, para qualquer fim, desde que atribua a autoria da obra, forneça um link para a licença, e indicar se foram feitas alterações. 
perpetuação do atraso, fruto da intocabilidade de seus meios de dominação. O sucesso desta iniciativa "bloqueadora" seria representado, politicamente, pela periódica aliança entre o partido administrador do "atraso", o chamado partido do interior, com o partido da classe média, debilitando a ascensão de um terceiro partido, o partido popular.

A tese dos três partidos, na obra de Singer, aparece a partir de um exercício comparativo entre as movimentaçôes político-partidárias de dois períodos da história contemporânea brasileira: o de 1945-1964 e o de 19892014. No primeiro período, os ditos partidos da classe média, popular e do interior seriam representados, respectivamente, pela UDN, o PTB e o PSD. No segundo momento histórico, estas mesmas agremiaçóes partidárias seriam ilustradas por PSDB, PT e PMDB. Assim, os partidos reais de ambos os períodos seriam estruturalmente os mesmos, conformando uma polarização entre os projetos de país do partido da classe média e do partido popular, representando um conflito mais amplo, com a centralidade da disputa entre ricos e pobres, ainda que a força social do subproletariado tendesse a desviar a estética do confronto para feiçóes populistas. Mediando esta contraposiçáo, estaria o partido do interior, representante do atraso e das relaçôes clientelistas.

A dinâmica do conflito partidário resultaria, na análise de Singer, em um singular problema para a democracia brasileira: uma vez ocorrido o realinhamento eleitoral - estabelecendo a polarização entre ricos e pobres, mediada pelo clientelismo do partido do interior - as dificuldades eleitorais do partido da classe média, incapaz de vencer as eleiçóes, estimulariam sua postura golpista, tendendo à radicalização de suas movimentaçóes em prol de uma solução não eleitoral para a disputa. Uma vez estabelecida esta situação, a agremiação do interior apareceria como o fiel da balança, podendo tanto estabilizar quanto desestabilizar a democracia.

Junto à hipótese geral, acerca do funcionamento da dinâmica partidária na democracia representativa brasileira, Singer apresenta outras três hipóteses de primordial importância para sua proposta: impulsionada pelo capital político lulista, Dilma teria forçado uma aceleração do projeto rooseveltiano, ilustrado em concomitantes ensaios desenvolvimentista e republicano; ao transitar do reformismo fraco ao reformismo forte, os ensaios 
provocaram reaçôes, impulsionando frentes politicas antidesenvolvimentistas e antirrepublicanas; diante da crescente oposição, a performance da presidente teria se tornado explicitamente errática, com sua desorientação programática aprofundando o isolamento do governo.

A idealização e aplicação dos chamados ensaio desenvolvimentista e ensaio republicano foram estabelecidas no primeiro ciclo do conjunto do governo Dilma, entre 2011 e 2013, caracterizado pelos altos índices de popularidade da presidente. Neste período, Dilma teria se afastado de parte das orientaçóes do período lulista, desequilibrando duas de suas principais vigas estruturantes: a relação com o capital financeiro e aliança com o partido do interior, o PMDB. Os protestos de junho de 2013 ilustrariam a transição para um segundo período, de 2013-2016, ao reduzirem, em poucos dias, a popularidade de Dilma de $57 \%$ para $30 \%$. Nesta segunda etapa, a frente desenvolvimentista seria cindida, com os industriais aderindo a uma campanha contra a intervenção estatal, enquanto a oposição ao ensaio republicano se aglutinaria no Congresso Nacional para forçar a derrubada do governo. A Operação Lava-Jato, surfando na onda republicana, prosseguiria os esforços de combate à corrupção iniciados por Dilma, mas capitalizaria estes em uma cruzada antilulismo que viria a ser apoiada nas ruas por diversos setores sociais.

Consubstanciado na chamada "nova matriz econômica", impulsionadora da redução dos juros para financiar a produção, o ensaio desenvolvimentista seria inicialmente apoiado pela aliança com os setores produtivos. No entanto, passaria, a partir de 2013, a sofrer com a oposição sistemática não apenas dos setores financeiros, mas inclusive da burguesia industrial, ao mesmo tempo em que o Banco Central passava a aumentar sistematicamente os juros, afrontando as diretrizes desenvolvimentistas do Ministério da Fazenda. Após as eleições de 2014, Dilma forçaria uma reaproximação com o rentismo, indicando Joaquim Levy para a Fazenda, mas seria incapaz de retomar a confiança dos industriais, que viriam a juntar forças com o partido do interior e o partido da classe média no entorno de um programa neoliberal, batizado de "Ponte para o futuro".

O ensaio republicano representaria uma ofensiva do governo contra determinadas relaçóes clientelistas enraizadas na política nacional, com o 
combate à corrupção visando a recuperação de parte da capacidade operacional do Estado, destacada por Singer como necessária à consecução do projeto desenvolvimentista. Este ensaio, que teve como sua pedra de toque a demissão, orquestrada por Dilma, de três diretores da Petrobras, afetava importantes interesses do partido do interior, o PMDB, e de outras siglas aliadas do governo. Ao contrariar estes interesses, Dilma passou a enfrentar, progressivamente, o inconformismo de antigos aliados, anseios que Eduardo Cunha viria a capitalizar politicamente para obstruir os projetos do governo na Câmara e insuflar, posteriormente, a queda da presidente.

Por um lado, o ensaio desenvolvimentista tentou estabelecer uma aliança entre os trabalhadores e a burguesia industrial, para acelerar o sonho rooseveltiano do lulismo, mas terminou por jogar esta mesma burguesia no colo da oposição, além de romper as antigas boas relaçóes do governo com os setores rentistas. Por outro, o ensaio republicano isolou politicamente o Governo, contribuindo para uma progressiva aproximação entre o partido do interior e o partido da classe média, que viriam a unificar, temporariamente, suas pretensóes em prol do processo de impeachment. Segundo Singer, a percepção desta situação de isolamento levou a um confronto de diretrizes entre Lula e Dilma, com o primeiro anunciando, desde 2012, a necessidade de reaproximação com o rentismo e o PMDB, enquanto a segunda persistia na tentativa de fortalecer os ensaios, ainda que viesse a abandonar o desenvolvimentismo em 2015, dando margem às acusaçóes de estelionato eleitoral, e, posteriormente, tentasse uma tardia reaproximação com o partido do interior, já às vésperas do impeachment, quanto entregou para Lula a articulação política do governo.

Pela complexidade dos eventos apresentados ao longo da obra, bem como pelo cuidado de Singer ao ilustrar o debate teórico concernente aos pontos que destaca, difícil se faz sintetizar a riqueza dos detalhes apresentados em seu mais novo livro. O próprio calor do momento no qual é escrito tende a conformar uma exposiçáo mais marcada pelo levantamento de questionamentos do que pelo de assertivas. Isso ficaclaro na própria conclusão da obra: ainda que tenha, por quase todo o desenvolvimento de sua argumentação, demonstrado o errático voluntarismo que forçou um autoisolamento do governo Dilma, Singer finaliza o texto atribuindo o fim do sonho rooseveltiano sem confronto às manobras da oposição, 
que teria feito questão de, à revelia das pretensóes lulistas, radicalizar o confronto com o governo. Sem dúvidas, há uma contradição entre a hipótese geral do trabalho, que atribui à burguesia industrial e ao partido do interior uma tendência pendular e estrutural ao alinhamento com o golpismo, e a sua própria argumentação, que demonstra o enorme peso das erráticas manobras políticas de Dilma para conformar seu cenário de completo isolamento. Ainda assim, de forma alguma esta observação retira do escrito de André Singer sua riqueza e ousadia, ao traçar, ainda que sem maior distanciamento histórico dos acontecimentos, uma complexa e original interpretação acerca de tão polêmico capítulo da história recente de nosso país. 